
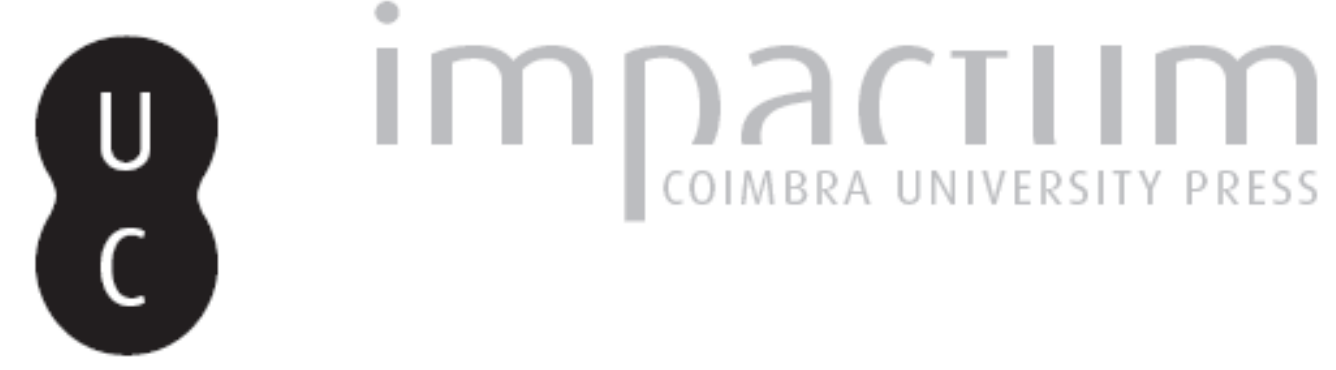

\title{
[Recensão a] Matthias Becker (2016), Porphyrios, Contra Christianos. Neue Sammlung der Fragmente, Testimonien und Dubia mit Einleitung. Übersetzung und Anmerkungen (Texte und Kommentare 52)
}
Autor(es):
Ramos, José Augusto

Publicado por: Centro de História da Universidade de Lisboa

URL

persistente:

URI:http://hdl.handle.net/10316.2/44054

DOI:

DOI:https://doi.org/10.14195/0871-9527_26_22

Accessed : $\quad$ 26-Apr-2023 16:15:38

A navegação consulta e descarregamento dos títulos inseridos nas Bibliotecas Digitais UC Digitalis, UC Pombalina e UC Impactum, pressupõem a aceitação plena e sem reservas dos Termos e Condições de Uso destas Bibliotecas Digitais, disponíveis em https://digitalis.uc.pt/pt-pt/termos.

Conforme exposto nos referidos Termos e Condições de Uso, o descarregamento de títulos de acesso restrito requer uma licença válida de autorização devendo o utilizador aceder ao(s) documento(s) a partir de um endereço de IP da instituição detentora da supramencionada licença.

Ao utilizador é apenas permitido o descarregamento para uso pessoal, pelo que o emprego do(s) título(s) descarregado(s) para outro fim, designadamente comercial, carece de autorização do respetivo autor ou editor da obra.

Na medida em que todas as obras da UC Digitalis se encontram protegidas pelo Código do Direito de Autor e Direitos Conexos e demais legislação aplicável, toda a cópia, parcial ou total, deste documento, nos casos em que é legalmente admitida, deverá conter ou fazer-se acompanhar por este aviso.

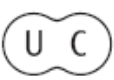




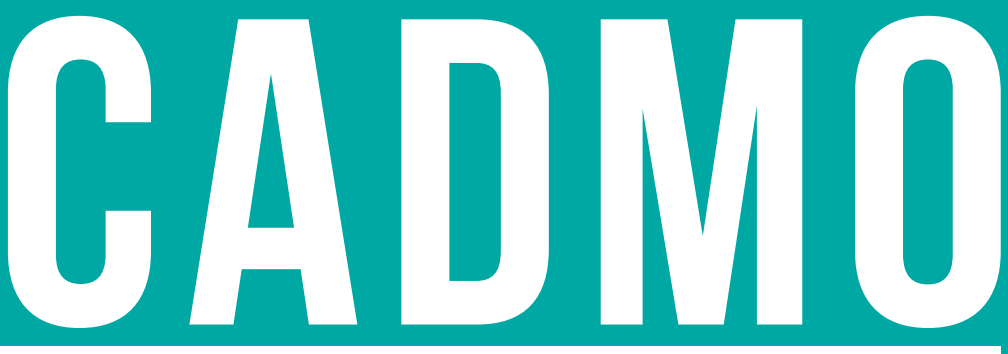

REVISTA DE HISTÓRIA ANTIGA JOURNAL FOR ANCIENT HISTORY

26

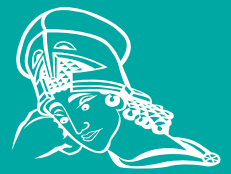

CENTRO DE HISTÓRIA DA UNIVERSIDADE DE LISBOA 2017 
O catálogo organiza-se por províncias, respectivamente, Lusitânia (p. 39), Bética (p. 57) e Tarraconense (p. 95). Um quarto subtítulo, Fuera de Catálogo (p. 147), agrupa as peças de proveniência desconhecida. Cada peça está acompanhada pelo respectivo comentário do A. e a sua tentativa de interpretação, assim como paralelos para achados semelhantes descobertos noutros locais, historial (sempre que este é conhecido), descrição, cronologia, dimensões e referências bibliográficas. As inscrições estão transcritas e traduzidas por Jaime Alvar, que ainda apresenta propostas de reconstrução quando estas se encontram incompletas. Fotografias de excelente qualidade suplementam estas informações e surpreendem o leitor habituado aos artigos publicados nas revistas da especialidade que nem sempre permitem um estudo da iconografia apresentada. No entanto, a identificação das mesmas só é feita no final da obra, no Índice de Ilustrações (pp. 189-192), onde se indica o número da foto, a procedência, a colecção a que pertence e ainda os créditos das fotografias. As Abreviaturas (pp. 169-170) e a extensa Bibliografia (pp. 171-188) encerram o volume, que, por infelicidade não inclui um índice geográfico para permitir uma rápida consulta através da toponímia.

Tal como aconteceu em Espanha, também em Portugal as campanhas arqueológicas realizadas nos últimos cinquenta anos revelaram um imenso manancial de informação e, várias peças descobertas em localidades portuguesas aparecem citadas, integradas nas respectivas províncias romanas. $\mathrm{Na}$ Lusitânia, estão assinaladas as cidades de Conímbriga, Padrão, Salácia, Tróia, Peroguarda, Pax Iulia, Santa Bárbara de Padrões, Vila do Bispo e, na Tarraconense, Bracara Augusta e o santuário de Panóias.

Em suma, é, como o seu autor desejou, uma ferramenta fundamental para todos os interessados na temática, complementando a extensa bibliografia de Jaime Alvar sobre o tema e, em particular, uma melhor compreensão da realidade peninsular e de como esta se integra no mundo romano da sua época.

Nídia Catorze Santos

Centro de História, Faculdade de Letras, Universidade de Lisboa

MATTHIAS BECKER (2016), Porphyrios, Contra Christianos. Neue Sammlung der Fragmente, Testimonien und Dubia mit Einleitung. Übersetzung und Anmerkungen (Texte und Kommentare 52), Berlin, De Gruyter, 667 pp., ISBN 978-3-11-044005-8 (€144.95).

Cem anos depois da $1^{a}$ edição desta obra por Adolf von Harnacks, Matthias Becker propõe-se nesta edição uma nova recolha dos fragmentos de Porfírio, procedentes do seu Contra Christianos, com novos textos a eles atinentes e uma tradução em alemão com comentários. Os textos pertinentes que representam a obra e o pensamento de Porfírio encontram-se repartidos entre fragmentos próprios, testemunhos de autores antigos e outros de carácter duvidoso.

Este livro, que tem como base uma tese de doutoramento do seu autor, divide-se em três partes: I. Uma introdução sobre Porfírio, o seu tempo e a sua obra e sobre as características desta obra de apresentação do antigo autor (3-112); II. Os conteúdos editados e estudados, relativos ao Contra Christianos (113-561); III. Em anexo, aparecem as abreviaturas técnicas, as diversas modalidades de bibliografia e os indispensáveis e numerosos índices (563-667). 
As observações valorizam e esclarecem pontos importantes relativamente a cada uma destas fontes, segundo as três categorias de autenticidade. Cada uma delas representa uma secção específica da segunda parte do livro: 1) 46 são fragmentos e testemunhos pertencentes a livros ou secções específicas do Contra Christianos; 2) 35 são fragmentos e testemunhos sem indicação de origem num livro definido do tratado de Porfírio, que são apresentados por temas; 3 ) 51 são textos duvidosos, ordenados por ordem cronológica.

O objectivo principal da obra, para além de recolher os materiais do tratado porfiriano em novos moldes, foi o de apreender e formular a maneira como Porfírio sentiu que o cristianismo constituía uma ameaça e como deu expressão literária a essas preocupações. A própria vida de Porfírio parece colocá-lo num relacionamento privilegiado com o cristianismo, num itinerário de linhas que se cruzam. O nascimento na cidade quase palestinense de Tiro acontece numa época em que, alguns quilómetros mais a sul, em Cesareia, pontificava o grande mestre cristão de origem alexandrina, Orígenes. Tenha Porfírio assistido ou não às aulas de Orígenes na escola de Cesareia, tenha pertencido realmente ao grupo dos cristãos e dele tenha eventualmente saído com qualquer dose de ressabiamento, o facto é que o mundo cultural de Porfírio se cruza inequivocamente com o do jovem cristianismo, quando este se encontrava em fase de entusiástica afirmação social e cultural. O conflito que se desenha processa-se num espaço cultural que aceita como plataforma e padrão epistemológico o helenismo de ressonâncias platónicas. É, por conseguinte, no interior de uma plataforma cultural comum que a dissensão se desenha. O conflito que aqui se desenrola torna-se por isso mais sugestivo e estimulante.

Tendo falecido nos primeiros anos do século IV, a vida de Porfírio decorreu no período imediatamente anterior à declaração constantiniana de licenciamento do cristianismo: eram tempos em que as ideias e as perspectivas se confrontavam com argumentos de parte a parte, no sentido de legitimar as respectivas posições. É mais um argumento para dar importância aos restos conservados desta obra de intervenção na consciência cultural e política do Império Romano. O tempo provável de redacção deverá ser colocado entre os anos de 270 e 303, possivelmente em Roma.

As fontes e temas discutidos no Contra Christianos são, numa parte significativa, recolhidos do Antigo Testamento segundo a tradução dos LXX. São nomeadamente os textos de Gn, Ex, Rt, 2Rs, 2Cr, Sl, Is, Ml, Dn, 1-2Mc. Incluem-se de seguida alguns livros do Novo Testamento, ainda não formalmente constituídos parte alternativa da Bíblia cristã, nomeadamente Mt, Mc, Lc, Jo, Act e Gl. São fontes analisadas sempre pelo seu texto em grego, dado que Porfírio não deveria saber hebraico. Seria possível questionarmo-nos sobre qual a língua natural de Porfírio enquanto cidadão da semítica cidade de Tiro. Era monolíngue de origem? E que relação cultivava com o fundo semita fenício de que esta cidade foi cabeça? Segundo Porfírio, por conseguinte, o espaço hermenêutico onde deve situar-se a discussão sobre o cristianismo é a matéria bíblica. Ela apresenta-se-lhe como a expressão da identidade do movimento cristão.

Outras fontes para o seu conhecimento do cristianismo são comentários onde afloram as matérias do Antigo Testamento. Particularmente bem conhecidas parecem ser igualmente as ideias cristãs transmitidas através das obras de Orígenes, mesmo algumas que não nos foram conservadas como os Stromates.

São particularmente ricas e numerosas as fontes filosóficas utilizadas na crítica que faz ao cristianismo; estas assentam principalmente na obra dos filósofos pagãos, especialmente os de 
orientação platónica. Esta base platónica era também importante no campo da hermenêutica cristã. Trabalhar sobre as mesmas coordenadas dá credibilidade à própria discussão. E é muito interessante perscrutar como os argumentos e incidências construtivas da mesma filosofia avançavam em duas direcções que os dinamismos da polémica momentaneamente pareciam contrapor.

Uma grande variedade de historiadores antigos, onde se inclui naturalmente a obra de Flávio Josefo, aparece no decorrer das análises de Porfírio, a propósito dos comentários sobre o livro de Daniel. Isto mostra mais uma vez a importância que têm as coordenadas do livro de Daniel na construção da visão histórica do cristianismo.

Não falta mesmo um caso de utilização da Ilíada para comparar o combate de Heitor e Aquiles com a luta entre Cristo e o Diabo. Pode ser uma temática marginal, mas que se tornou significativa no imaginário cristão.

A ameaça que Porfírio vê e de que responsabiliza o cristianismo é a de uma ruptura civilizacional. Segundo Porfírio, essa ameaça de ruptura dessolidariza o mundo configurado pelo cristianismo daquele outro mundo que estava moldado pela religiosidade tradicional. Neste sentido, o cristianismo era percebido e transmitia sensação de ameaça (Bedrobungskommunikation) como um factor de desarticulação do Império Romano. Porfírio representa, desta maneira, a perspectiva oposta àquela que acabou por vingar na linha constantiniana, a qual seria entendida como uma dinâmica de coesão para o mesmo Império. A ameaça apontada atingia o sistema jurídico-político, representando o desmoronar do mesmo pelas virtualidades anómicas de um certo libertarismo e anarquismo cristão. Verificamos, entretanto, que pouco tempo mais tarde, Constantino faz e perfaz uma leitura completamente oposta sobre o horizonte histórico que se projecta com o cristianismo. Face a esta ameaça, Porfírio vê a adesão ao cristianismo por parte de Orígenes e o seu abandono por parte de Amónio Sacas como dois caminhos contrapostos e teoricamente contraditórios. A dinâmica conflitual implicada nesta densidade hermenêuticocultural dos finais do séc. III coincide com um período de fortes perseguições dirigidas contra o cristianismo. Nesta perspectiva, o Contra Christianos poderia também representar o discurso hermenêutico-cultural justificativo das perseguições.

É já muito notória uma espécie de hibridismo cultural no cristianismo daqueles primeiros séculos. Por isso verificamos que a matéria de discussão são os dados bíblicos analisados segundo padrões de origem grega. Pressupõe-se que a base de discussão seja mutuamente reconhecida. Porfírio entende a literatura bíblica como histórias que se devem sempre compreender à letra, de modo que a sua hermenêutica não pode servir-se dos métodos de alegoria que, bem ao contrário, são a marca da interpretação grega (75-76). Onde assenta este literalismo aplicado à leitura da Bíblia? A exegese judaico-cristã que tinha já naquela altura uma longa prática não justifica semelhante restrição. Pelo contrário, a transposição metafórica é o processo de raciocínio hermenêutico preferido na literatura bíblica e a prática judaico-cristã não fez mais que acentuar esse processo.

Os pontos e as estratégias de ataque ao cristianismo, coloca-os Porfírio sobretudo no âmbito das coordenadas específicas da concepção de Deus, sublinhando particularmente as suas implicações no modo de entender a cristologia. Em suma, trata questões estruturais de fundo que mantêm alguma pertinência para todas as eras da História. É, portanto, útil continuar a ler Porfírio.

Outra estratégia consiste em sublinhar pormenores da literatura bíblica facilmente tratados 
como defeitos das personagens ou criticar as figuras e as realidades do cristianismo seu contemporâneo. Desagrada-lhe que os pensadores cristãos sejam tão facilmente caracterizáveis como "sofistas" (81) e que nas suas comunidades as mulheres possam ter tanta influência como se fossem membros de um autêntico senado (85).

O conteúdo do Contra Christianos insere-se na longa esteira histórica de discussão sobre as razões e valências do cristianismo como promotor de ideias e coordenadas de vida, tanto para os indivíduos como para a sociedade. O cristianismo é um messianismo e o messias é a metáfora hipostática de uma sociedade ideal. Estas matérias discutidas sobre o cristianismo na obra de Porfírio são convergentes com as que foram tratadas na "Bíblia dos Pagãos", a Biblia Gentium (Giancarlo Rinaldi, Biblia Gentium: Primo contributo per un indice delle citaz̧ioni, dei riferimenti e delle allusioni alla Bibbia negli autori pagani, greci e latini di età imperiale. Roma, 1989, Libreria Sacre Scritture, bilingue: italiano e inglês).

Os textos desta obra de Porfírio ficaram registados apenas nos textos dos numerosos autores cristãos que, na antiguidade, decidiram participar nesta intensa e prolongada discussão. O processo moderno e contemporâneo de estudo, recolha e edição dos mesmos a partir dos tempos modernos constitui de igual modo um complexo percurso colectivo que teve na edição de Adolf von Harnack, em 1915, um marco significativo. Entretanto o interesse pelo tema e os dados a ele referentes foram crescendo ao longo do século que desde então decorreu. A ciência está hoje apetrechada de instrumentos e dados capazes para novas apresentações do material. A presente edição é um caso entre outros, que têm andado a investigar a obra porfiriana com métodos e coordenadas diversificadas e com objectivos específicos.

Neste sentido, a parte mais longa desta obra, justamente aquela que junta os textos de referência porfiriana, a sua tradução em alemão e os comentários e observações para cada texto (115-561) são o mais valioso instrumento de trabalho que se nos oferece. É neste espaço que se deverá continuar a investir para iluminar as questões históricas e hermenêuticas. Também do ponto de vista de uma recensão esta imensa quantidade de dados e comentários se torna impossível de tratar com pormenor. O serviço que está chamada a prestar cumprir-se-á na profundidade e diversidade dos estudos de cada investigador, a quem pode servir de grande ajuda.

Sendo muitas as alternativas possíveis no estudo, ponderação, atribuição, contextualização e organização editorial, uma qualidade da presente edição está no facto de estabelecer uma chave de correspondência entre os materiais aqui apresentados e os que já foram apresentados em outras edições anteriores mais relevantes (108-112).

A autonomização de uma III parte como anexo (563-667) tem inteira justificação, considerando as mais de cinquenta páginas de bibliografia e a importância dos índices de referências bíblicas, autores antigos e medievais, nomes de pessoas, nomes geográficos e referências temáticas. Numa edição que é simultaneamente base de dados justifica-se amplamente.

As razões que justificam um interesse tão intensamente renovado pela obra de Porfírio prendem-se com a importância que a obra deste autor representa na antiguidade, situado como está na encruzilhada entre as culturas clássico-helenística e a oriental, entre as fórmulas de vida representadas pelo cristianismo emergente e pelo paganismo tradicional e entre maneiras alternativas de se enquadrar no sistema de ideias platónico e neoplatónico, que era acolhido com natural atractivo por parte de ambas linhas de pensamento de que as polémicas de Porfírio nos trazem testemunho. A transcendência das interrogações que aqui se jogam acaba por se repercutir com igual pertinência sobre a totalidade 
da nossa história cultural e hermenêutica. Aqui estão as razões para se considerar actual e pertinente a obra de Porfírio e consequentemente meritória esta nova publicação e estudo sobre a mesma.

José Augusto Ramos

Centro de História, Faculdade de Letras, Universidade de Lisboa

ADELE REINHARTZ (2013), Bible and Cinema - An Introduction. New York, Routledge, 286 pp. ISBN 978-0-415-77948-7 (31.00€)

Professora do Departamento de Estudos Clássicos e Religiosos da Universidade de Ottawa, no Canadá, tendo como áreas de especialização o "Novo Testamento", as "relações iniciais judaicocristãs" ou a "Bíblia e o Cinema", Adele Reinhartz é também editora-chefe da Journal of Biblical Literature. Com uma vasta lista de livros e artigos dedicados a estes temas, foi com base na obra anterior e na sua experiência de Professora que publicou este Bible and Cinema, título a que corretamente apensou An Introduction. Além das opções tomadas ao nível do conteúdo, também a forma por que optou na construção do livro evidencia a influência que a sala de aula teve na publicação, que aposta numa lista de tópicos alargada, privilegiando a apresentação das várias vias que os estudos da receção da Bíblia podem seguir. Este é um livro que serve como uma introdução alargada, qual cadeira de preparação, onde a (feliz) escolha de apresentar as notas e respetiva bibliografia no final de cada capítulo reforça a impressão de estarmos a seguir aulas mais do que a ler um livro - facilitando a tarefa a quem desejar aprofundar um determinado tópico.

O livro de Adele Reinhartz propõe levar-nos por uma viagem introdutória e vasta desde os primórdios do cinema (final do séc. XIX) até às mais recentes produções à data do livro, passando por uma imensa quantidade de filmes que, de uma forma ou de outra, são incontornáveis na análise às diferentes roupagens e aproveitamentos bíblicos feitos pelo grande ecrã. A A. porém, não se limita às produções incontornáveis, abordando também filmes que à primeira vista não julgaríamos que entrassem neste conjunto de obras.

As páginas que nos chegam às mãos, escritas de forma simples e bastante fluida, fáceis de acompanhar, mais do que cumprem o objetivo a que Reinhartz se propõe, num livro que não sendo excessivamente exaustivo em focos particulares é muito eficaz. Talvez por essa razão, o livro surge não só com uma introdução geral (pp. 1-13) como com introduções-síntese a abrir cada capítulo, apresentando os traços gerais dos temas abordados. E apesar de se iniciar nos primórdios do cinema, o ângulo do livro não se limita à verticalidade do tempo, avançando também pela horizontalidade do espaço, já que apesar do domínio da produção cinematográfica por parte dos EUA, também a receção da Bíblia pelo cinema inglês, italiano ou canadiano, entre outros, são tidos em conta. Mas o predomínio é norte-americano: o cinema que chega dos EUA, pelo seu maior alcance global, tem um peso como nenhum outro. E falando nós de uma expressão artística que já por si é das mais influentes, sendo mesmo fonte primordial (ou única) do conhecimento que milhares - ou milhões - retêm, tal torna o estudo da receção essencial: "With regard to reception history, the study will document amply, though not exhaustively, the movies' use of both the Bible and other modes of 